\title{
The Issue of Food Security in Cuba ${ }^{1}$
}

José Alvarez ${ }^{2}$

On October 28, 2000, U.S. President Bill Clinton signed the Trade Sanctions Reform and Export Enhancement Act (TSRA) which allowed U.S. firms to sell food and agricultural products to Cuba and other countries. However, the Cuban government did not purchase any of these products until December of 2001 following the devastating damage caused by Hurricane Michelle to important agricultural areas in November of that year.

Cuban purchases from U.S. firms amounted to $\$ 4.319$ million in 2001, \$138.635 million in 2002, and $\$ 256.9$ million in 2003. Cuba became the 35th most important food and agricultural export market for the United States in 2003, up from last (226th) in 2000. Actual purchases and pending contracts in the first-half of 2004 are at a pace to move Cuba into the top 20 most important markets of U.S. food and agricultural exports. Furthermore, because current U.S. legislation requires that all Cuban purchases from the United States must be conducted on a cash basis, the lack of credit risk associated with these sales makes Cuba one of the most attractive export markets for U.S. firms.

Anticipating changes in U.S.-Cuba trade relations, the Food and Resource Economics
Department at UF/IFAS initiated a research initiative on Cuba in 1990, including a 1993 collaborative agreement with the University of Havana, which has lasted to this day. (Most of the resulting publications can be found at http://www.cubanag.ifas.ufl.edu). We reiterate that our role as investigators is to provide the best available information and analyses from which rational decisions can be made. The reports included in this series intend to address the increasing level of interest in the Cuban market for food and agricultural products among U.S. firms and to assist them in becoming more familiar with that market. The complete list of documents in this series can be found by conducting a topical search for "Cuba" at http://edis.ifas.ufl.edu, or under "Additional Information" at the end of this document.

\section{Introduction}

Since the establishment of the food rationing system in 1962, the issue of food security has been an important one in Cuban life. This fact sheet tries to provide an answer to the question: Are Cubans adequately fed? But, before doing that, it is necessary to define a series of related terms useful in understanding the methodology of the Food and

1. This is EDIS document FE483, a publication of the Department of Food and Resource Economics, Florida Cooperative Extension Service, UF/IFAS, University of Florida, Gainesville, FL. Published July 2004. Please visit the EDIS website at http://edis.ifas.ufl.edu.

The author would like to thank the University Press of Florida (http://www.upf.com) for permission to reproduce material from the book Cuba's Agricultural Sector (Alvarez, 2004).

2. José Alvarez, Professor, Department of Food and Resource Economics, Everglades Research and Education Center, Belle Glade, FL, Florida Cooperative Extension Service, UF/IFAS, University of Florida, Gainesville, FL.

The Institute of Food and Agricultural Sciences is an equal opportunity/affirmative action employer authorized to provide research, educational information and other services only to individuals and institutions that function without regard to race, color, sex, age, handicap, or national origin. For information on obtaining other extension publications, contact your county Cooperative Extension Service office. Florida Cooperative Extension Service/Institute of Food and Agricultural Sciences/University of Florida/Christine Taylor Waddill, Dean. 
Agriculture Organization of the United Nations for determining nutritional status.

\section{Definition of Terms}

Food Insecurity: low levels of food intake, which can be transitory (when it occurs in times of crisis) or seasonal/chronic (when it occurs on a continuing basis).

Food Security: access by all people at all times to the food needed for a healthy and active life. Achieving food security means ensuring that sufficient food is available, that supplies are relatively stable, and that those in need of food can obtain it.

Malnutrition: physiological condition resulting from inadequacy or imbalance in food intake or from poor absorption of food consumed.

Micronutrient Deficiency: lack of essential vitamins and minerals resulting from unbalanced food intake and specific problems of absorption of food consumed.

Undernourishment: chronic food insecurity in which food intake is insufficient to meet basic energy requirements on a continuing basis.

Undernutrition: the result of prolonged low-level food intake and/or poor absorption of food consumed. Manifestations include wasting (low weight-for-height), stunting (low height-for-age) or underweight, reduced cognitive ability, poor health status, and low productivity.

\section{FAO's Methodology for Nutritional Status}

There are two distinct and useful measures of nutritional status derived from different analytical approaches. Undernourishment is estimated from existing data about numbers of people and the amount of food available to them. Undernutrition is determined from data about individuals' weight, height, and age. Ratios calculated from these measurements indicate the outcome not only of inadequate food intake, but also of poor health and sanitation conditions that may prevent people from deriving full nutritional benefit from what they eat. The two approaches, as expected, are complementary.

Data to determine undernourishment are country-specific are based on energy requirements for each sex-age group, taking into account sex-age specific heights within the population. Since they vary from country to country, these data must be used with caution when making comparisons between countries and time periods. Food intake measurements, on the other hand, rely on data that are more readily available, recent, and fully comparable across countries. They can be used effectively to obtain a snapshot of current conditions, even though they do not capture the full array of factors determining nutritional status.

\section{FAO's Nutritional Requirements}

Foods supply the body with energy in the form of carbohydrates, fats, and proteins. It also provides the body with amino acids, vitamins, and minerals, all of which are needed for growth and for the maintenance of cells and tissue. Information on nutritional requirements are provided by FAO (1973; 1974).

Energy requirements are a function of a multitude of variables such as sex, age, activities, body size and composition, and climate. The FAO/WHO Expert Committee on Energy and Protein Requirements (FAO 1973; 1974) recommended that the average energy requirement of men and women be regarded as unchanging from 20 to 39 years of age. The energy requirement decreases by $5 \%$ for each decade between the ages of 40 and 59, and by $10 \%$ for ages between 60 and 69 , while reductions of another $10 \%$ are recommended for ages 70 and above.

Proteins can be classified as either "animal proteins" or "vegetable proteins." Animal proteins contain more of the essential amino acids than do vegetable proteins and, in general, have a higher nutritive value. The Joint FAO/WHO Expert Group, after considering numerous studies, arrived at a figure of 0.57 grams and 0.52 grams per day for each kilogram of body weight for men and women, respectivley, as the safe level of protein intake in 
terms of cow's milk or egg protein. However, in reality, populations subsist mainly on mixed proteins of animal and vegetable origin rather than on the egg or milk proteins used to express the safe levels of protein intake. The nutritive value of such mixed protein intake can be determined by biological methods and, since vegetable proteins possess a lower nutritive value, more such protein is required to satisfy the requirements.

As a community prospers, its diet becomes more varied. Higher consumption of animal protein foods, fats, and oils increases the energy level of the diet and thus furthers protein utilization. It is important to realize that practical nutrition is concerned with the nutritive value of diets, not of individual foods.

Human nutritional requirements are country specific. FAO has developed the minimum daily requirements for Cuba. They include 2,400 calories (kcal), 75 grams of fat, and 72 grams of protein (29 from animal origin and 43 from vegetable origin).

\section{Standardized Food Balance Sheets: Definition and Methodologies}

A food balance sheet presents a comprehensive picture of the pattern of a country's food supply during a specified period of time. For the primary commodities and a number of processed products, it shows the potential availability for human consumption, the sources of supply, and their utilization. The total quantity of foodstuffs produced in a country added to the total quantity imported and adjusted for any change in stocks that may have occurred since the beginning of the reference period gives the supply available during that period. On the utilization side, a distinction is made between the quantities exported, fed to livestock, used for seed, put to manufacture for food use and non-food uses, losses during storage and transportation, and food supplies available for human consumption. The per capita supply of each such food item available for human consumption is then obtained by dividing the respective quantity by the related data on the population actually partaking of it. Data on per capita food supplies are expressed in terms of quantity, caloric value, and protein and fat content.
Annual food balance sheets show trends in the overall national food supply, disclose changes that may have taken place in the types of food consumed (the pattern of the diet), and reveal the extent to which the country's food supply is adequate in relation to nutritional requirements. In addition, they are useful to appraise the food and agricultural situation of a country, making it possible to calculate import dependency ratios, signaling the degree to which primary food resources are used to produce animal feed, and helping project food demand.

Food available for human consumption relates simply to the food reaching the consumer. Waste on the farm and during distribution and processing is taken into consideration as an element in the food balance sheet. One of the major causes of food waste in some developing countries (and Cuba is a good example) is the lack of organization and inadequate marketing and distribution systems. Much of the food remains unsold because of imbalances in supply and demand or the failure to get available food supplies to the locations where they are needed. This is particularly true of perishable foods such as fresh fruits and vegetables.

The accuracy of food balance sheets, which are in essence derived statistics, is dependent on the reliability of the underlying basic statistics of population, supply and utilization of foods, and nutritive value of food. These vary greatly between countries. The production and trade statistics on which the accuracy of food balance sheets depends most are, in many cases, subject to improvement through the organization of appropriate statistical field surveys. Surveys for waste, for example, are almost nonexistent. In most cases, waste figures are based on expert opinion obtained in the countries. The use of both internal and external consistency checks help in evaluating the statistics provided. While being far from satisfactory in the proper statistical sense, the food balance sheets are valuable and useful for a variety of purposes, particularly for showing relative changes over time.

\section{Cuba's Food Balance Sheets}

FAO's food balance sheets provide the means for analyzing Cuba's situation concerning nutrition 
(daily per capita intake of calories, proteins, and fats), food waste, and food import dependency.

\section{Daily Per Capita Intake of Calories, Protein, and Fat, 1982-1999}

As discussed earlier in this fact sheet, FAO's minimum daily nutritional requirements for Cuba are 2,400 Kcal of calories, 75 grams of fat, and 72 grams (29 and 43 grams of animal and vegetable origins, respectively) of proteins. What is Cuba's record with regard to the nutrition of its population? To address that question, the data presented by FAO, the Cuban government, and some Cuban scholars are examined.

Cuban figures reported to FAO came from the following sources:

- the rationing system.

- food sold at subsidized prices in public institutions such as dining rooms in factories, schools, nurseries, and in cafeterias and stands.

- food distributed in places such as hospitals and nursing homes.

- food produced in rural and urban self-provisioning plots sold by workers or farmers.

- food purchased in other food outlets such as the recently created parallel markets.

Data collected from so many different sources by many different organizations are very likely to contain intentional and/or accidental errors that result in inconsistencies. Unfortunately, the Cuban government suspended the delivery of data to FAO at the end of the 1990s. (The author tried to contact the FAO office in Havana, Cuba, to check if they had more data available but to no avail; the electronic messages went unanswered.)

Daily per capita intakes of calories, proteins, and fats for the period 1980-1999 are shown in Figure 1. They show the data from FAO and the official data combined with those of some Cuban authors [FAO's data were taken from http://www.fao.org.] Official Cuban statistics were obtained from CEE (various issues), and from Campbell (2000), Ferriol Muruaga
(1996), and Nova González (2000)]. The gap between the two sets is significant concerning calories, relatively small for proteins, and much greater for fat in later years. FAO data, as explained above, concluded in 1997.

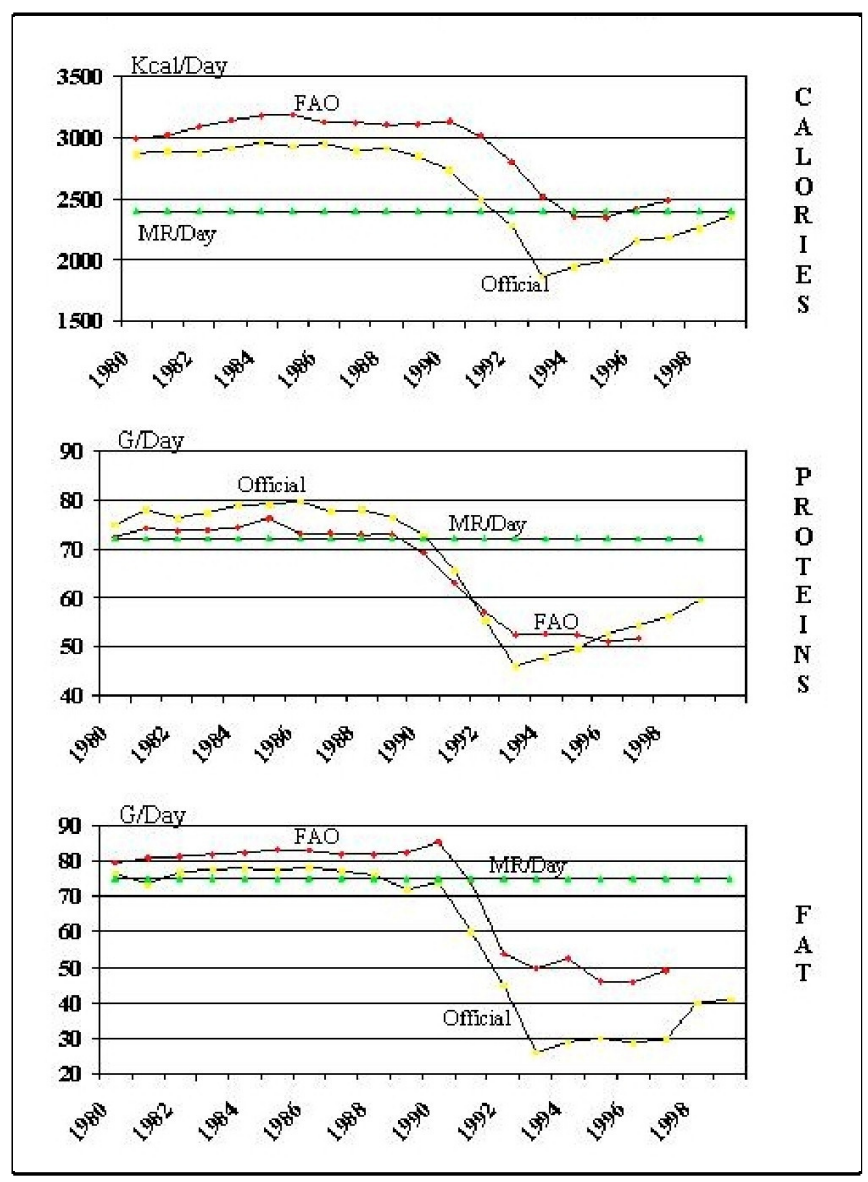

Figure 1. Daily per capita intake of calories, proteins, and fat, and FAO's minimum requirements (MR), 1980-1999.

From 1980 until 1991 in the official Cuban data and until 1993 for FAO data, Cuba exceeded the minimum daily requirements of 2,400 calories. Although they had been decreasing since 1989 and 1991, respectively, it is not until 1992 and 1994 that the intake falls below 2,400 calories. The pattern is different regarding proteins. From 1980 until 1989, the figures remained very close above the minimum daily requirement of 72 grams; after that year, they decreased abruptly and have remained below the minimum requirement. Data for fat intake behaves similarly to that for proteins. In the 1980s, levels of fat intake were slightly above the minimum daily requirement of 75 grams. Since 1988, according to the official data, and 1991 for the FAO data, fat intake levels of 75 grams per day remain below the 
minimum daily requirement. It is obvious that these low levels coincide with the establishment of the "Special Period in Time of Peace" (a series of measures announced by the Cuban government in September of 1991 which was intended to deal with the economic hardships brought to Cuba by the collapse of the Soviet bloc). The startling finding, however, is that, although the Cuban government supplied the numbers to FAO, the official statistics in Cuba's official Anuario Estadístico are not only below those of FAO, but they are reported to have begun decreasing even before the establishment of the Special Period in all three cases (1989 for calories, fats, and proteins), with fat being the one showing the worst scenario. When the daily per capita intake of calories, proteins, and fats is broken down by animal and vegetable sources, the decreases experienced in the three nutritive measures were greater from animal sources, which have higher nutritive value than vegetable sources.

A cursory survey of the literature reveals discrepancies in several areas by different authors. For example, a comprehensive study on the nutritional status of Cubans at the beginning of the 1980s was summarized in the following manner:

The nutriture of today's Cubans appear to be better than that of the average third world country. This is not unexpected since moderate and severe malnutrition are not that commonly prevalent in the Caribbean as a region. It does not appear, however, that the nutriture of Cubans, both objectively and subjectively, is better today than during the so-called prerevolutionary years. Aside from the unending argument regarding the effects of redistribution through rationing, the per-capita caloric intake has remained essentially unchanged considering the limitations of nutritional data obtained from food balance sheets (Gordon, 1983, p. 30).

Other scholars, however, consider Cuba's nutritional performance a relative success. It is the result, according to Amador and Peña (1991), of a number of measures implemented by the Cuban government. One of the factors directly related to food and nutrition was the establishment of the
National Food and Nutrition Surveillance System in 1977. Monckerberg (1981) stated that, despite the different economic systems present in Chile and Cuba, both countries "have developed systems of intervention which are comparable and similarly successful" (p. 120).

Comments and assessments after the Special Period, including those of Cuban authors, do not include the word "success." Ferriol Muruaga (1996) states that the changes in Cuba's economy between 1989 and 1993 impacted in a negative manner the health and nutritional status of the population. Reports included the following: (1) the worsening of the nutritional status of mother and baby; (2) an increase in the number of newborns below normal weights; (3) decreasing nutritional levels for pregnant women and children younger than one year of age; (4) increasing numbers of deaths from infectious diseases and tuberculosis; (5) death of the elderly due to low nutritional levels; (6) micronutrient deficiencies; and (7) increase in illnesses from food poisoning.

Perhaps the problem with the most negative impact on the health of Cubans, the one that generated more attention within and outside Cuba, was the epidemic of optic and peripheral neuropathy from late 1991 to mid-1993. A delegation of five scientists from the United States were invited by both "The U.S. + Cuba Medical Project" (based in New York) and Cuba's Ministry of Health to travel to the island to work with their Cuban counterparts in researching and eliminating this epidemic. In a subsequent report, Tucker and Hedges (1993) estimated the number of cases as 50,000. Although a few other causal hypotheses were studied, Tucker and Hedges stated that, "it is generally believed that an interaction of some toxin or toxins, in combination with nutritional deficiency, is likely to be the major cause" (p. 349). The fact is, after the Cuban government began distributing vitamin supplements to every citizen in April 1993, the epidemic appeared to be controlled by mid-1993 (p. 349). Some minor outbreaks of a different nature have been reported in subsequent years but have apparently been controlled before reaching epidemic proportions. 
According to Ferriol Muruaga (1996), achieving an adequate availability of food products is a necessary condition for decreasing nutritional problems. In fact, the 2,218 kilo-calories consumed daily by Cubans after the establishment of the Special Period fall short of the recommended 2,400 calories as discussed above. In the worst moment of the Special Period, according to Vice-President Lage, the daily per capita consumption of calories went down to less than 2,000 while that of protein decreased to 47 grams, both well below the recommended minimum daily requirement (Granma, September 29, 2000).

\section{Food Waste in Relation to Food Available}

Food availability is the result of a number of factors, with food waste as one of them. As noted in a previous section of this fact sheet, another use of food balance sheets is the quantification of a country's food waste measured against the amount of food available for consumption. Figures for some of Cuba's perishable commodities have been provided to FAO by the Cuban government for the 1980-1997 period (Table 1). During the entire study period, more than 4.3 million tons of these products (an average of almost 240,000 tons per year) were wasted. The ratio of food waste over food available ranged from more than $10 \%$ to almost $15 \%$.

Processed products or those that need refrigerated facilities are not considered. The perishable products selected include starchy roots, vegetables, and fruits. The first reaction to the figures is that they are low when compared with scattered statistics and anecdotal evidence about the inefficiencies of the state collection agency (EDIS FE484). One has to recall that country officials are the ones who provide gross estimates in the absence of surveys. In the case of Cuba, the figures are highly suspect.

\section{Import Dependency Ratios}

The food balance sheets contain data on food imports and food available for consumption. A general background to start this section is provided by two interesting paragraphs by Cuban authors. In 1993, Nova González wrote:
Despite possessing an important proportion of fertile soils, some availability of underground water, favorable climatic conditions with two well-defined dry and wet periods, and sun all year round; despite these general favorable conditions for agricultural production during all months [of the year], Cuba has historically imported an important volume of food, many of those food products can be substituted and/or decreased through national production (p. 76).

Nieto and Delgado wrote a few years later:

Despite the investments made in infrastructure during decades, and the application of science and technology, agricultural activities [in Cuba] could not achieve the country's self-sufficiency in food, [still] depending to a large extent on the complement of imports of food and raw materials for their processing, in addition to the majority of inputs (2001, p. 47).

Data on food imports and on food available for consumption facilitate the computation of import dependency ratios (Table 2). Recalling the caveats concerning FAO data, several observations can be made. For the period 1980-1997 (last year of FAO data), the general trend is one of decreasing ratios; that is, imports have become a smaller percentage of total food available for consumption. In 1980, Cuba imported $70 \%$ of the food available for consumption. In the following years, the import dependency ratios experienced modest decreases. One has to remember that those were the years of special commercial arrangements with the Council for Mutual Economic Assistance (CMEA) when Cuba imported high levels of food products. In the last years of the 1990s (since the establishment of the Special Period), the ratio has decreased considerably.

Interesting results are obtained when one compares Cuba's import dependency ratios before and after the 1959 revolution. The figures for the 1980-1997 period range from a low of 42\% in 1997 to a high of $70 \%$ in 1980. As reported by Nova González (1993, p. 76), data taken from official Cuban sources of that time include $31 \%$ in 1954 , $23.3 \%$ in 1955 , and $20.7 \%$ in 1956 . It is obvious that, 
with the passage of time, Cuba has become more dependent on foreign sources to feed its population.

A two-article study by García Alvarez et al. (1996; 1997) addresses the issue of import substitution of foodstuffs as "a necessity that cannot be postponed." The two articles are part of a base study that will provide the basis for plans to reduce imports while increasing domestic production. Only time will tell if those plans will materialize.

\section{References}

Alvarez, José. 2004. Cuba's Agricultural Sector. Gainesville, FL: University Press of Florida.

Amador, Manuel, and Manuel Peña. 1991. Nutrition and Health Issues in Cuba: Strategies for a Developing Country. Food and Nutrition Bulletin 13 (4): 311-317.

Campbell, Al. 2000. The Cuban Economy Has Turned the Corner: The Question Now Is Where Is It Going? In Cuban Transitions at the Millennium, edited by Eloise Linger and John Cotman, pp. 167-203. Largo, MD: International Development Options.

Comité Estatal de Estadísticas (CEE). Annual issues. Anuario Estadístico de Cuba. La Habana: Oficina Nacional de Estadísticas.

Food and Agriculture Organization of the United Nations (FAO). 1973. Necesidades de Energía y de Proteinas. Rome, Italy: FAO and World Health Organization.

Food and Agriculture Organization of the United Nations (FAO). 1974. Handbook on Human Nutritional Requirements. Rome, Italy: FAO.

Ferriol Muruaga, Angela. 1996. La Seguridad Alimentaria en Cuba. Cuba: Investigación Económica 2 (3, July-September): 31-54.

García Alvarez, Anicia, Isis Mañalich Gálvez, Nieves Pico García, and Nancy A. Quiñones Chang. 1996. La Sustitución de Importaciones de Alimentos: Una Necesidad Impostergable. Primera Parte. Cuba: Investigación Económica 2 (4, October-December): 1-36.
García Alvarez, Anicia, Isis Mañalich Gálvez, Nieves Pico García, and Nancy A. Quiñones Chang. 1997. La Sustitución de Importaciones de Alimentos: Una Necesidad Impostergable. Segunda Parte. Cuba: Investigación Económica 3 (1, January-March): 1-49.

Gordon, Jr., Antonio M. 1983. The Nurtiture of Cubans: Historical Perspective and Nutritional Analysis. Cuban Studies 13 (2, Summer): 1-34.

Monckerberd B., Fernando. 1981. The Possibilities for Nutrition Intervention in Latin America. Food Technology 35 (9): 115-121.

Nieto, Marcos and Ricardo Delgado. 2001. El Sector Agrario y la Seguridad Alimentaria. In Transformando el Campo Cubano - Avances de la Agricultura Sostenible, edited by F. Fuenes, L. García, M. Bourque, N. Pérez and P. Rosset, pp. 39-56. La Habana, Cuba: Asociación Cubana de Técnicos Agrícolas y Forestales.

Nova González, Armando. 1993. Cuba: ¿Modificación o Transformación Agrícola? Mimeographed article. La Habana, Cuba.

Nova González, Armando. 2000. La Economía Cubana en la Década de los 90. Enfoques, Segunda Quincena (February).

Tucker, Katherine, and Thomas R. Hedges. 1993. Food Shortages and an Epidemic of Optic and Peripheral Neuropathy in Cuba. Nutrition Reviews 51 (12): 349-357.

\section{Additional Information}

Below is a list of the fact sheets in this series on Cuban Agriculture. They can be accessed by clicking on the highlighted links:

- FE479 - Cuban Agriculture Before 1959: The Political and Economic Situations

- FE480 - Cuban Agriculture Before 1959: The Social Situation

- FE481 - Transformations in Cuban Agriculture After 1959 
- FE482 - Overview of Cuba's Food Rationing System

- FE483 - The Issue of Food Security in Cuba

- FE484 - Acopio: Cuba's State Procurement and Distribution Agency

- FE485 - Antecedents of the Cuban Agricultural Policies of the 1990s

- FE486 - Chronology of Cuban Reform Policies with Emphasis on Agriculture, 1993-1995

- FE487 - Cuba's Basic Units of Cooperative Production

- FE488 - Cuba's Agricultural Markets

- FE489 - Environmental Deterioration and Conservation in Cuban Agriculture

- FE490 - The Potential Correlation between Natural Disasters and Cuba's Agricultural

Performance 
Table 1. Food wasted in relation to food available in Cuba for selected perishable commodities, 1980-1997. ${ }^{a}$

\begin{tabular}{|c|c|c|c|}
\hline Year & Food Waste & Food Available & Waste Available $^{\mathrm{b}}$ \\
\hline & \multicolumn{2}{|c|}{1,000 metric tons } & percent \\
\hline 1980 & 213 & 1,816 & 11.73 \\
\hline 1981 & 234 & 1,920 & 12.19 \\
\hline 1982 & 214 & 1,740 & 12.30 \\
\hline 1983 & 251 & 1,738 & 14.44 \\
\hline 1984 & 269 & 1,821 & 14.77 \\
\hline 1985 & 264 & 2,012 & 13.12 \\
\hline 1986 & 244 & 1,918 & 12.72 \\
\hline 1987 & 253 & 1,903 & 13.29 \\
\hline 1988 & 285 & 2,157 & 13.21 \\
\hline 1989 & 252 & 1,927 & 13.08 \\
\hline 1990 & 249 & 2,006 & 12.41 \\
\hline 1991 & 251 & 2,007 & 12.51 \\
\hline 1992 & 259 & 2,118 & 12.23 \\
\hline 1993 & 214 & 1,854 & 11.54 \\
\hline 1994 & 192 & 1,677 & 11.45 \\
\hline 1995 & 200 & 1,918 & 10.43 \\
\hline 1996 & 235 & 2,205 & 10.66 \\
\hline 1997 & 238 & 2,298 & 10.36 \\
\hline $\begin{array}{ll}\text { a } & \text { Includes st } \\
\text { b } & \text { Calculated } \\
\text { Source: http:/ }\end{array}$ & getables, an & a reporting was & after 1997. \\
\hline
\end{tabular}


Table 2. Relationship between Cuba's selected food imports and food available for consumption, 1980-1997.

\begin{tabular}{|c|c|c|c|}
\hline Year & Food Available for Consumption & Imports & Import Dependency Ratio \\
\hline & \multicolumn{2}{|c|}{1,000 metric tons } & percent \\
\hline 1980 & 5,554 & 3,928 & 70.7 \\
\hline 1981 & 5,837 & 3,633 & 62.2 \\
\hline 1982 & 5,596 & 3,131 & 55.9 \\
\hline 1983 & 5,642 & 3,376 & 59.8 \\
\hline 1984 & 5,765 & 3,332 & 57.8 \\
\hline 1985 & 6,068 & 3,517 & 57.9 \\
\hline 1986 & 5,895 & 3,403 & 57.7 \\
\hline 1987 & 5,856 & 3,542 & 60.5 \\
\hline 1988 & 6,141 & 3,600 & 58.6 \\
\hline 1989 & 5,968 & 3,596 & 60.2 \\
\hline 1990 & 5,852 & 3,397 & 58.0 \\
\hline 1991 & 5,588 & 2,869 & 51.3 \\
\hline 1992 & 5,118 & 2,394 & 46.8 \\
\hline 1993 & 4,837 & 2,534 & 52.4 \\
\hline 1994 & 4,697 & 2,350 & 50.0 \\
\hline 1995 & 4,877 & 2,265 & 46.4 \\
\hline 1996 & 4,994 & 2,142 & 42.9 \\
\hline 1997 & 5,172 & 2,172 & 42.0 \\
\hline $\begin{array}{ll}\mathrm{a} & \text { Data rep } \\
\mathrm{b} & \text { Imports } \\
\text { Source: } \mathrm{ht}\end{array}$ & $\begin{array}{l}\text { suspended after } 1997 . \\
\text { ood available for consumption. C. } \\
\text { o.org. }\end{array}$ & he author. & \\
\hline
\end{tabular}

